\title{
KRITIK MOESLIM ABDURRAHMAN TERHADAP BUDAYA KONSUMERISME KEIAS MENENGAH
}

\author{
Oleh: \\ Joko Arizal \\ Sekolah Pascasarjana Fisipol Universitas Gadjah Mada \\ Joko.arizal@mail.ugm.ac.id
}

\begin{abstract}
This article explains Moeslim Abdurrahman's view on the Indonesian Muslim middle class. The emergence of Muslim middle class in Indonesia was helped by New Order regime's success in implementation of economic development and modernization. Their political attitude is mostly apolitical, their Islam is more culturally oriented, and they are a part of an increasingly consumerist society. It reveals that the combination between consumerism and religious attitude in this class creates a new type of pious social class. The research discusses the new middle class daily life style signified by the glamorous, trendyness, and prestigeousness of religious symbols and attributes. Their religious appearance and attitude show the shifting meaning of religion from the substantial to the material. The form of their religious life actually reduces the true meaning of Islam which promotes equality and social justice. The religious attitude of the new middle class Muslim has been losing its critical and emancipative function.
\end{abstract}

Key words: Islam, Muslim Middle-Class, Consumerism

\section{A. Pendahuluan}

Developmentalisme yang menjadi agenda utama rezim Orde Baru berdampak terhadap perubahan stratifikasi sosial di Indonesia. Salahsatu bentuk perubahan stratifikasi sosial itu adalah munculnya suatu kelas sosial, yaitu kelas menengah baru (new middle class). Kelas menengah baru yang dimaksud ini terdiri dari para pekerja profesional, teknokrat, kalangan terpelajar atau akademisi.

Perkembangan kelas menengah yang dari masa ke masa kian pesat dapat meningkatkan pertumbuhan ekonomi Indonesia. Daya beli masyarakat kelas menengah terhadap produk dalam negeri dan produk impor mampu memicu perputaran ekonomi. Menurut Bank Dunia (World Bank), kelas menengah Indonesia mengalami pertumbuhan yang sangat signifikan. Data Bank Dunia tahun 2011 menunjukkan, 56,5\% dari 237 juta populasi Indonesia masuk kategori kelas menengah. Kategori kelas 
menengah versi Bank Dunia adalah mereka yang membelanjakan uangnya 2 dollar AS sampai 20 dollar AS per hari. Artinya, saat ini ada sekitar 134 juta warga kelas menengah di Indonesia. ${ }^{1}$

Di bidang politik, kehadiran kelas menengah sangat berperan dalam partisipasi politik, terutama dalam proses demokratisasi. ${ }^{2} \mathrm{Hal}$ ini menunjukkan kelas menengah merupakan aktor atau agen perubahan sosial, karena mereka memiliki kemampuan lebih besar secara ekonomi, lebih berpendidikan, dan posisi secara sosial yang terpandang atau terhormat.

Namun, hasil survei Litbang Kompas tahun 2011 memperlihatkan sebagian besar kelas menengah Indonesia lebih tertarik pada hal-hal yang bersifat material. ${ }^{3}$ Perkembangan kelas menengah ini menjadi cukup mengkhawatirkan, karena pola konsumsi mereka semakin menggelora untuk menikmati komoditas barang-barang hasil produksi, dan menyebabkan kelas menengah terjerat dan terperangkap dalam budaya konsumtif atau dikenal dengan konsumerisme. Jika Rene Descartes mengatakan, cogito ergo sum (Aku berpikir, maka Aku ada), maka dalam konteks ini, emo ergo sum (Aku berbelanja, maka Aku ada).

Budaya konsumerisme merupakan sebuah budaya konsumsi yang ditopang oleh proses penciptaan diferensiasi secara terus-menerus lewat penggunaan objek-objek komoditas, sebuah budaya belanja yang proses perubahan dan perkembangbiakannya didorong oleh logika hasrat dan keinginan ketimbang logika kebutuhan. Aktivitas konsumsi yang sebelumnya berkaitan dengan pemenuhan nilai fungsi, kini dimuati dengan nilai-nilai status, simbol dan prestise. Budaya konsumerisme menciptakan rasa ketidakpuasan abadi terhadap penampilan, fungsi, dan penampakan citra objek-objek komoditas. Hal ini dilakukan dengan menciptakan kebutuhan yang bukan esensial, melainkan artifisial. Budaya konsumerisme mengkonstruksi perasaan kurang atau perasaan tidak sempurna pada diri setiap orang dalam hal kepemilikan objek dan mendorong mereka untuk terus mengonsumsi. Melalui mesin produksi kapitalisme, orang dikondisikan untuk menginginkan sesuatu yang tidak dibutuhkannya. ${ }^{4}$

${ }^{1}$ http://bisniskeuangan.kompas.com/read/2011/12/19/07433945/Kelas.Meneng ah.Tidak.Diantisipasi, diakses 20 Maret 2016.

${ }^{2}$ M. Dawam Rahardjo, Masyarakat Madani: Agama, Kelas Menengah dan Perubahan Sosial, (Jakarta: LP3ES dan LSAF, 1999), hlm. 268.

3 Ninuk M. Pambudy, "Gaya Hidup Suka mengonsumsi dan Meniru: Beranikah Berinovasi?”, Prisma, Vol. 31, No. 1 (2012), hlm. 16.

4 Yasraf Amir Piliang, Bayang-Bayang Tuhan: Agama dan Imajinasi, (Bandung: 
Di samping pola dan gaya hidup kelas menengah yang konsumtif, fenomena lain yang mencolok dari kelas menengah baru Indonesia adalah semangat kembali pada kehidupan agama, khususnya kelas menengah yang beragama Islam. Ketika masyarakat digempur oleh perubahan sosial yang cepat, maka kebutuhan terhadap hal-hal yang spiritual mengalami intensifikasi. Vatikiotis mengatakan, bahwa telah terjadi gejala dislokasi sosial yang luas dan menghinggapi masyarakat yang sedang berubah cepat. Banyak orang kemudian kembali pada agamanya untuk memperteguh diri sebagai reaksi atas hancurnya tatanan nilai-nilai moral sosial tradisional yang terjadi di sekitar mereka. ${ }^{5}$

Karena pola dan gaya hidup kelas menengah terbangun dari budaya konsumerisme, hal itu memberikan pengaruh terhadap pola keberagamaan mereka. Konsumerisme bersama ideologi yang dibawanya telah mempengaruhi berbagai bentuk kehidupan, termasuk kehidupan keagamaan. Agama dan praktek keagamaan, baik secara sadar maupun tidak sadar telah menjadi bagian dari skema budaya konsumerisme. Konsumerisme merupakan bagian yang tak terpisahkan dari ideologi ekonomi kapitalisme, di dalamnya kebudayaan diciptakan sebagai bagian dari logika pasar dan komoditas. Agama, khususnya praktek ritual keagamaan menjadi bagian dari komoditas tersebut. Ia dikembangkan dalam rangka mencari keuntungan. ${ }^{6}$ Dalam hal ini kelas menengah atau dalam bahasa lainnya disebut orang kaya baru (OKB) menjadi segmen pasar para pemilik modal. Untuk memenuhi hasrat kelas menengah ini, para pemilik modal mengkonstruksi dan menciptakan simbol atau atribut yang mampu menampilkan citra yang bersifat religius, bermerek dan bergengsi.

Bukti kecil dari ketaatan tersebut mudah ditemui seperti ramainya simbol-simbol, atribut-atribut dan event-event (pengajian) keagamaan (Islam) di ruang publik. Barangkali kita tidak asing dengan munculnya pengajian-pengajian di hotel mewah, pelaksanaan haji dan umroh melalui biro perjalanan yang dilengkapi fasilitas mewah, zikir bersama dengan berurai air mata, menyerbaknya penggunaan hijab atau jilbab, peci, baju koko, mengantungkan kaligrafi dan lain sebagainya. Simbol, atribut, dan event tersebut menjadi identitas baru yaitu sebagai penanda kesalehan sosial dan prestise.

Mizan, 2011), hlm. 71.

5 Michael R.J Vatikiotis, Political Change in Southeast Asia, Trimming the Banyan Tree, (London and New York: Routledge, 2005), hlm. 155.

${ }^{6}$ Yasraf Amir Piliang, Bayang-Bayang Tuhan: Agama dan Imajinasi, hlm. 69. 
Pertautan perilaku kelas menengah yang konsumtif dengan menguatnya ketaatan mereka terhadap ajaran Islam telah membentuk identitas dan budaya baru di Indonesia. Inilah yang menjadikan pewacanaan kelas menengah muslim amat urgen dan menarik. Selama ini, kajian terhadap kelas menengah di Indonesia lebih menekankan pada aspek politik dan ekonomi. Amat sedikit yang mengkaji kelas menengah dalam aspek sosial-keagamaan secara serius dan kritis.

Untuk itulah, dalam tulisan ini, penulis secara khusus mendiskursuskan pemikiran Moeslim Abdurrahman. ${ }^{7}$ Moeslim merupakan cendikiawan muslim yang terlibat di berbagai aktivitas sosialpolitik. Dalam ranah akademik, salah satu yang menjadi concern-nya adalah perkembangan dan perilaku kelas menengah muslim Indonesia dalam dimensi sosial-keagamaan. Di sini, perilaku kelas menengah muslim yang akan kita soroti adalah budaya konsumerisme yang telah menggurita dalam kehidupan beragama.

\section{B. Pembahasan}

\section{Konsumerisme}

Konsumsi di dalam The Concise Oxford Dictionary berarti pemanfaatan dan penggunaan barang-barang. Ada juga yang mendefiniskan konsumsi sebagai pemilihan, penggunaan, pemeliharaan, perbaikan dan pembagian produksi atau jasa. ${ }^{8}$ Bila konsumsi merupakan tindakan, konsumerisme merupakan sebuah cara hidup (a way of life). Konsumsi merupakan cermin aksi yang tampak, sedangkan konsumerisme lebih terkait dengan motivasi yang terkandung di dalamnya.

Embrio konsumerisme muncul pasca revolusi industri di Eropa di mana kapitalisme memiliki peran yang dominan dalam sistem sosial. Sebagai ideologi, konsumerisme bisa dikatakan turunan dari sistem kapitalisme dalam proses perkembangannya yang evolutif. Semakin

7 Dalam sketsa pemikiran Islam Indonesia, Moeslim tidak dapat dipisahkan dari gerbong pembaharuan pemikiran Islam pada tahun 1970-an. Figur-figur utama yang menjadi lokomotif pembaharuan Islam di antaranya Nurcholish Madjid, M. Dawam Rahadjo, Djohan Effendi, Ahmad Wahib, Usep Fathuddin, Utomo Dananjaya, Abdurrahman Wahid, Imaduddin Abdurrahim, Jalaluddin Rahmat, Kuntowijoyo, M. Amien Rais dan lain sebagainya. Berdasarkan hasil riset Yudi Latif, semua intelektual tersebut merupakan generasi keempat dari intelegensia muslim abad ke-20. Sebagian besar mereka adalah aktivis HMI, PII dan mengeyam pendidikan di IAIN. Lihat Yudi Latif, Intelegensia Muslim dan Kuasa: Genealogi Intelegensia Muslim abad ke-20, (Bandung: Mizan, 2005), hlm. 660.

${ }^{8}$ Soedjatmiko, Saya Berbelanja, Maka Saya Ada, (Jogjakarta: Jalasutra, 2008), hlm. 28.

$60 \quad$ JURNAL LISAN AL-HAL 
berkembangnya ekonomi kelas menengah, konsumerisme muncul melalui semangat dan upaya untuk menandai diri dengan barang-barang produksi sehingga orang terkesan berbeda dari yang lain, lebih bahagia, lebih mewah, lebih segalanya, dan mampu menciptakan dan mengekspresikan identitas diri di tengah pergaulan sosial masyarakat. ${ }^{9}$ Spirit ini tumbuh seiring perkembangan teknologi-informatika dan didorong pula oleh industrialisasi, urbanisasi, dan pertumbuhan penduduk. Masyarakat pun mulai menganut prinsip budaya self-expression untuk memacu aktivitas konsumsi.

Oleh karenanya, konsumerisme tidak dapat dipisahkan dari wacana kapitalisme global yang di bangun atas iklim persaingan yang tinggi antara perusahan dan produser, persaingan ketat dalam gaya hidup. Kebudayaan dikonstruksi atas dasar prinsip perbedaan penampilan, gaya hidup yang selalu dibuat berubah dengan tempo yang semakin tinggi. ${ }^{10}$

Menurut Jean Baudrillard, konsumsi bukan sekedar hasrat untuk membeli berbagai komoditas, tapi suatu fungsi kenikmatan, fungsi individual, pembebasan kebutuhan, pemuasan diri, kekayaan atau konsumsi objek. Konsumsi berada dalam satu tatanan pemaknaan pada satu "panoply" objek; suatu sistem, atau kode, tanda; "satu tatanan manipulasi tanda"; manipulasi objek sebagai tanda; satu sistem komunikasi (seperti bahasa); satu sistem pertukaran (seperti kekerabatan primitif); satu moralitas, yaitu satu sistem pertukaran ideologis; produksi perbedaan; satu generalisasi proses mode secara kombinatif"; menciptakan isolasi dan mengindividu; satu pengekang secara bawah sadar, baik dari sistem tanda dan dari sistem sosio-ekonomiko-politik dan satu logika sosial. ${ }^{11}$

Konsumsi dalam perspektif Baudrillard dipahami sebagai sistem tanda berdasarkan penafsiran terhadap tanda (simbol-simbol) sosial, antara lain: perbedaan kelas sosial, gender, dan ras. Baudrillard memakai istilah yang dipakai oleh Bourdieu, bahwa perbedaan kelas tersebut disebut sebagai distinction, dimana kelas dominan membedakan diri melalui 3 struktur konsumsi, yaitu: makanan/minuman, budaya, dan

9 M. Nur Prabowo, "Meretas Kebahagiaan Utama di Tengah Pusaran Budaya Konsumerisme Global: Perspektif Etika Keutamaan Ibn Miskawaih", Mukaddimah, Vol. 19, No. 1 (2013), hlm. 67.

10 Yasraf Amir Piliang, Dunia yang Dilipat: Tamasya Melampaui Batas-Batas Kebudayaan, (Bandung: Matahari, 2010), hlm. 416.

${ }^{11}$ George Ritzer, "Introduction", on Jean Baudrillard, The Consumers Society: Myths and Structures, (London: Sage, 1998), hlm. 15-16. 
penampilan. ${ }^{12}$ Melalui 3 struktur konsumsi tersebut perbedaan, tingkat konsumsi antara kelas sosial yang satu dengan lainnya nampak dalam nilai atau kualitas objek konsumsi walaupun fungsi utamanya sama. Perbedaan pendidikan, gender, keturunan, pekerjaan, kedudukan, kemampuan berbelanja, berpengaruh terhadap kesempatan dan kepemilikan terhadap objek yang berbeda. Perbedaan inilah yang menjadi ciri masyarakat konsumsi dalam memahami hakikat konsumsi. Menurut Baudrillard hanya ada satu makna dalam logika sosial konsumsi, yaitu makna pembeda. ${ }^{13}$

Dalam era konsumerisme, masyarakat hidup di dalam satu bentuk relasi subjek dan objek yang baru, yaitu relasi konsumerisme. Dalam masyarakat konsumer, objek-objek konsumsi dipandang sebagai ekspresi diri atau eksternalisasi para konsumer, dan sekaligus sebagai internalisasi nilai-nilai sosial-budaya yang terkandung di dalamnya. ${ }^{14}$

Objek-objek yang dikonsumsi tidak hanya sekedar menghabiskan nilai guna dan nilai utilitasnya, akan tetapi juga untuk mengkomunikasikan makna-makna tertentu. Di sini, seakan-akan objek konsumsi dikontrol oleh subjek (konsumer). Boro-boro mau menguasai simbol, status, prestise lewat objek-objek konsumsi, justru kita terperangkap di dalam sistemnya. Ketimbang aktif di dalam tindakan penciptaan dan tindakan kreatif, para konsumer justru lebih tepat disebut mayoritas yang diam (silent majority). Bagi kelompok ini yang dicari di dalam konsumsi bukan lagi makna-makna ideologis melalui tindakan sublasi, melainkan kegairahan dan ekstasi dalam pergantian objek-objek konsumsi.

Di dalam konsumsi yang dilandasi oleh nilai tanda dan citraan dari pada utilitas, logika yang mendasarinya bukan lagi logika kebutuhan melainkan logika hasrat. Hasrat ini tidak akan pernah dipenuhi, karena ia selalu direproduksi dalam bentuk yang lebih tinggi atau disebut dengan mesin hasrat. Sekali hasrat dicoba dipenuhi lewat substitusi objek-objek hasrat, maka yang muncul hanya hasrat yang lebih tinggi dan sempurna lagi. Resiko yang segera tampak dari arus hasrat perbedaan yang tak putus-putus adalah ia dapat menenggelamkan subjek yang dikuasainya di dalam kawasan tanda, simbol atau nilai-nilai yang bersifat tumpang

12 Fadhilah, "Relevansi Logika Sosial Konsumsi dengan Budaya Konsumerisme dalam Perspektif Epistemologi Jean Baudrillar", Jurnal Kybernan, Vol. 2, No. 1 (Maret 2011), hlm. 53.

13 Jean Baudrillard, The Consumers Society: Myths and Structures, (London: Sage, 1998), hlm. 59.

14 Yasraf Amir Piliang, Dunia yang Dilipat: Tamasya Melampaui Batas-Batas Kebudayaan, hlm. 148. 
tindih, simpang siur dan kontradiktif. Sifat tumpang-tindih, simpang-siur dan kontradiktif ini juga mencirikan masyarakat konsumer. ${ }^{15}$

Budaya konsumerisme dapat dikatakan sebagai teror halus terhadap diri dan masyarakat. Dalam pengertian bahwa setiap orang atau kelompok orang dikondisikan dalam rasa takut (paranoia); takut ketinggalan mode, takut menjadi tua, takut tidak trendly, takut tidak bergaya, takut tidak langsing, kulit tidak putih dan lain sebagainya. Teror halus ini menggiring setiap orang untuk terperangkap di dalam irama pergantian citra dan gaya hidup oleh badai hasrat tanpa akhir, sehingga tidak mempunyai ruang lagi bagi peningkatan kualitas dan identitas diri yang otentik.

Di dalam masyarakat konsumer, setidaknya terdapat tiga bentuk kekuasaan yang beroperasi di belakang produksi dan konsumsi objekobjek, yaitu kekuasaan kapital, kekuasaan produser, dan kekuatan media massa. ${ }^{16}$ Kekuasaan kapital dan produser sangat menentukan objek-objek konsumsi baik secara kuantitatif maupun kualitatif. Sedangkan media massa terkait dengan periklanan. Bagaimana objek-objek konsumsi mampu menarik dan membangkitkan hasrat konsumen untuk membeli produk tersebut. Bagi masyarakat ini, apa yang dicari di dalam konsumsi bukan lagi makna-makna ideologis melalui tindakan sublasi, melainkan kegairahan ekstasi di dalam pergantian objek-objek konsumsi.

\section{Wacana Kelas Menengah di Indonesia}

Di Indonesia, perbincangan kelas menengah secara ilmiah mencuat pada tahun 1984 yang dipelopori oleh majalah Prisma. Dua tahun kemudian berlangsung seminar "The Politics of Middle Class Indonesia" di Monash University, Australia. Di dalam seminar itu, para ilmuwan sosial baik dari Indonesia maupun negara lainnya memaparkan tentang apakah ada fenomena kelas menengah, kriteria keanggotaannya, dan peran sosial dalam dinamika dan dialektika perpolitikan Indonesia. Namun, pemahaman konsep kelas menengah di kalangan ilmuwan tersebut sungguh beragam, ironisnya mereka tak mencapai kesepakatan secara ontologis, malah cenderung bersifat taken for granted.

Keberadaan kelas menengah di Indonesia tidak memiliki legitimasi historis sebagaimana yang terjadi di masyarakat Barat. Kelas menengah di Barat lebih mapan, mandiri dan independen dari kekuasaan. Sehingga

15 Ibid., hlm. 150.

16 Yasraf Amir Piliang, Dunia yang Dilipat: Tamasya Melampaui Batas-Batas Kebudayaan, hlm. 148. 
keberadaan mereka sangat menentukan perubahan-perubahan sosial, ekonomi dan politik. Sedangkan di masyarakat Indonesia, pada umumnya kelas menengah mengalami ketergantungan dengan pemerintah dan/atau perusahaan.

Di Indonesia, kelas menengah tumbuh di perkotaan, seperti Jakarta, Bandung, Jogjakarta, Surabaya, Makassar, Palembang, Medan, dan lain-lain. Pertumbuhan mereka tak dapat lepas dari faktor peningkatan ekonomi yang pesat dan kemajuan sistem pendidikan yang merupakan bagian dari program pemerintah. Faktor-faktor tersebut sangat mempengaruhi profesi, pendapatan, pola dan gaya hidup. Kondisi ini pula yang menjadi daya tarik dan role mode masyarakat di daerah untuk menjadi bagian masyarakat kota melalui urbanisasi. Sehingga dari tahun ke tahun jumlah kelas menengah semakin meningkat.

Dari sisi ekonomi, World Bank mengkriteriakan kelas menengah yaitu mereka yang mengeluarkan atau membelanjakan 2 dollar hingga 20 dollar per hari. Asia Development Bank (ADB) pun memakai kerangka yang sama dengan World Bank. ADB lebih mengembangkan kategorisasi kelas menengah dari sisi pengeluarannya yaitu masyarakat kelas menengah bawah (lower middle class) dengan pengeluaran perkapita perhari sebesar \$2-4; kelas menengah tengah (middle-middle class) sebesar \$4-10; dan kelas menengah atas (high middle class) \$10-20.17 Dari rentang pengeluaran \$2-20, berdasarkan hasil riset Word Bank pada tahun 2012 jumlah kelas menengah di Indonesia mencapai 56,5\% dari 237 juta penduduk Indonesia atau sekitar 134 juta orang masuk kategori kelas menengah. Namun, besarnya angka ini harus diberi catatan karena hanya 14 juta orang saja yang punya kemampuan berbelanja \$6-20 perhari. ${ }^{18}$ Artinya, secara umum masyarakat Indonesia berada pada kelas menengah bawah.

Perlu dicatat, kelas menengah sesungguhnya tidak hanya ditentukan secara kuantitatif dengan indikator pendapatan dan pengeluaran. Berbagai indikator kualitatif lain bisa juga digunakan untuk mengukur kelas menengah, seperti pendidikan, profesi, bahkan indikator psikografis seperti tingkat melek investasi, wawasan pengetahuan, atau kesadaran partisipasi politik. Jika ukuran-ukuran ini dimasukkan, maka kriteria kelas menengah menjadi semakin ketat dan agaknya jumlah kelas

17 http://www.yuswohady.com/2012/11/26/siapa-kelas-menengah/ diakses 20 Maret 2016.

${ }^{18}$ http://bisniskeuangan.kompas.com/read/2011/12/19/07433945/Kelas.Menen gah.Tidak.Diantisipasi, diakses pada 20 Maret 2016.

64 JURNAL LISAN AL-HAL 
menengah di Indonesia tidak sebesar yang diduga banyak kalangan. ${ }^{19}$

Pada tataran empiris, ada kelompok orang yang dilihat dari segi ekonominya belum tergolong kelas menengah, tetapi ditinjau dari sisi sosial dan politik sudah dapat kita golongkan sebagai kelas menengah. Karena jumlahnya yang sedikit dan tanpa dukungan ekonomi yang kuat, mereka tidak dapat membentuk suatu lapisan yang tangguh untuk mengambil inisiatif terhadap gagasan-gagasan pembaharuan dan perubahan. Di sisi lain, terdapat kelompok orang yang secara ekonomi sudah mapan, tidak dapat masuk dalam kategori kelas menengah, karena tidak memiliki keinginan untuk melakukan perombakan dan perubahan sosial. ${ }^{20}$ Contoh lainnya, ibu rumah tangga yang hanya mengurus keluarga bisa masuk kelas menengah karena berpendidikan tinggi dan memiliki suami yang kaya. Kondisi real seperti inilah yang menyebabkan para ilmuwan sosial mengalami kesulitan untuk mengidentifikasi kelas menengah Indonesia.

Di samping itu, untuk mempermudah memahami keberadaan dan pembentukan kelas menengah, setidaknya kita harus mengamati beberapa kriteria-kriteria berikut, yaitu: pertama, derajat urbanisasi (menjadi masyarakat kota); kedua, perluasan dan peningkatan pendidikan; ketiga, perluasan industri-industri manufaktur dan tersier serta tingkat ketersediaan lapangan kerja; keempat, pemilikian tanah mewah, khususnya di perkotaan; kelima, penghasilan-penghasilan bisnis dari kegiatan-kegiatan komersial dan industri; keenam, penghasilan investasi (dari saham, bunga atau deposito atau pinjaman dan lain-lain); ketujuh, kredit-kredit murah yang disediakan pemerintah, penghasilan tambahan bagi pegawai kantor dan tunjangan. ${ }^{21}$

Dari kriteria-kriteria di atas, kita dapat menjelaskan siapa yang dimaksud dengan kelas menengah. Mereka itu adalah kalangan terpelajar atau akademisi, profesional, teknokrat, intelektual, pengusaha-pengusaha kecil. Secara umum, mereka mandiri, mapan, dan tidak tergantung pada negara.

\section{Islam, Kelas Menengah dan Konsumerisme Menurut Moeslim Abdurrahman}

${ }^{19}$ Noorhaidi Hasan, Kelas Menengah Muslim dan Pemimpin Indonesia Masa Depan, Jurnal Maarif, Vol.8, No. 2 (2013), hal. 115

${ }^{20}$ Soetjipto Wirosardjono, Kelas Menengah Mencari Bentuk dan Pengakuan, Prisma, XIII, No. 2 (Februari 1986), hal. 71-72.

21 J.A.C. Mackie, Uang dan Kelas Menengah, dalam Richard Tanter dan Kenneth Young, Politik kelas menengah Indonesia, (Jakarta: LP3ES, 1996), hal. 122-126. 
a. Islam

Pengalaman Moeslim bergulat dengan realitas sosial sangat mempengaruhi pemahaman pribadinya mengenai Islam. Ketika di pesantren, konsep Islam yang ia pahami sesuai dengan apa yang diajarkan oleh Kyai, yaitu bersifat normatif. Setelah selesai dari pesantren dan masuk dunia universitas serta bersentuhan langsung dengan realitas sosial inilah pemahaman Moeslim tentang Islam mengalami pergeseran paradigmatif dan melampaui konsep sebelumnya.

Menurut Moeslim, makna Islam yang paling murni bukan terletak pada rumusan teologisnya (apalagi yang telah dibakukan oleh ulama), justru muncul dalam pergulatan sehari-hari para umatnya untuk menegakkan cita-cita keadilan. Islam adalah ruh kemanusian yang paling sejati yang menuntun peradaban, terutama dalam pemerdekaan dan pembebasan (liberation), baik bagi kesadaran orang per orang maupun secara kolektif, untuk mewujudkan keadaban (amar bi al ma'ruf) dan peradaban dalam arti menghidupkan cita-cita kemanusiaan yang merdeka, bebas dan terhormat (nahy munkar). ${ }^{22}$

Kebenaran yang berlandaskan pemerdekaan bukanlah terletak pada kemampuan bagaimana hebatnya wacana dan nalar yang dirumuskan. Justru kriteria dasar untuk melihat apakah makna Islam telah menggerakkan emansipasi kemanusiaan haruslah dilihat dari proses empiris yang sedang berlangsung. Dengan demikian Islam menjadi gagasan sejarah yang bergerak, dan bukan sekedar memperkaya khazanah intelektual yang mengambang, tidak jelas memihak dan melakukan penghadangan terhadap proses dehumanisasi dan marginalisasi sosial. ${ }^{23}$

Moeslim ingin mencari moda interpretasi orto-praksis, bagaimana mempertautkan (bahkan mengkonfrontasikan) hubungan antara iman dengan realitas perubahan sosial. Karena tujuan risalah Islamiyah adalah bagaimana ide agama dalam pergulatan hidup secara kolektif berperan dalam menegakkan tatanan sosial yang adil, sebagai cita-cita ketakwaan. ${ }^{24}$ Moeslim mengupayakan bagaimana mengaitkan Islam sebagai ideologi perubahan yang menggugah kesadaran emansipatoris, terutama yang bersifat struktural dan bukan Islam sebagai kegiatan dakwah yang terlalu mengutamakan kesalehan ritual. Baginya, Islam merupakan agama yang prinsip-prinsipnya tidak hanya didasarkan pada ritual atau spiritual

${ }^{22}$ Moeslim Abdurrahman, Suara Tuhan, Suara Pemerdekaan, (Jogjakarta: Kanisius, 2009), hlm. 7.

${ }^{23}$ Ibid., hlm. 8.

${ }^{24}$ Moeslim Abdurrahman, Islam sebagai Kritik Sosial, (Jakarta: Erlangga, 2003), hlm. 6.

66 JURNAL LISAN AL-HAL 
spekulatif, tapi yang paling fundamental ialah menjaga agar nilai-nilai kemanusiaan tidak dimanipulasi atau secara moral diselewengkan oleh sejarah. ${ }^{25}$

Kalau kita amati konsep Islam yang dipahami oleh Moeslim, jelaslah Islam yang dimaksud adalah Islam yang mampu menggugah kesadaran emansipatoris yang membawa pada perubahan sosial. Moeslim sendiri memproklamirkan bahwa konsep keislamannya adalah Islam transformatif. Sangat wajar jika Budhy Munawar-Rahman memposisikan Moeslim dan pemikir lainnya seperti M. Dawam Rahardjo, Adi Sasono, Mansour Faqih, Masdar Farid Mas'udi, M. Habib Chirzin dalam tipologi pemikiran neo-modernisme Islam Indonesia pada tipologi Islam transformatif. Pada umumnya mereka adalah para ahli ilmu-ilmu sosial yang meminati teologi, dan atau sebaliknya, para teolog yang hendak memakai analisis sosial radikal. ${ }^{26}$ Di antara tokoh-tokoh itu, Moeslim-lah yang paling getol menggunakan istilah "transformatif" yang tidak hanya disandingkan pada kata "Islam", tetapi dengan kata lainnya. Hal ini dapat kita amati di dalam tulisan-tulisannya, seperti wahyu transformatif, pendidikan transformatif, dakwah transformatif, dan Islam transformatif itu sendiri. Adalah suatu kewajaran manakala istilah Islam transformatif lebih dominan dinisbahkan pada Moeslim Abdurrahman.

Dalam pandangan Moeslim, Islam transformatif pada dasarnya adalah sebuah impian teologis, yakni bagaimana makna agama bisa diperebutkan oleh mereka yang terpinggirkan, bukan dalam adu otoritas tentang siapa yang boleh menafsirkan dan tidak boleh menafsirkan makna suci, tetapi bagaimana Islam boleh menjadi ruh pembelaan bagi mereka yang sengsara. Islam transformatif bekerja dengan menghubungkan refleksi teologis dengan pembacaan konstruk masyarakat agar dapat menimbulkan gerakan-gerakan transformasi sosial. ${ }^{27}$

b. Kelas Menengah

Di dalam buku Islam Sebagai Kritik Sosial, Moeslim menyatakan bahwa "kelas menengah di Indonesia lebih mudah dirasakan daripada didefinisikan."28 Berangkat dari pernyataan itu Moeslim tidak mendefinisikan secara spesifik apa itu kelas menengah. Ia cenderung melihat perkembangan dan cara kelas menengah muslim mengungkapkan keberislaman di Indonesia. Corak dan ekspresi pengungkapan Islam di

\footnotetext{
25 Moeslim Abdurrahman, Islam yang Memihak, (Jogjakarta: LKiS, 2005), hlm. 1.

${ }^{26}$ Budhy Munawar-Rahman, Islam Pluralis, (Jakarta: Paramadina, 2001), hlm. 336.

27 Moeslim Abdurrahman, Islam sebagai Kritik Sosial, hlm. 186.

28 Ibid., hlm. 34.
} 
ruang publik tidak lepas dari faktor ekonomi, sosial, politik, psikologi dan pendidikan yang berbeda-beda.

Latar belakang pendidikan dan karir pekerjaan dari kelompok ini membedakannya dari kelas menengah lama (pemilik usaha dan pabrik kecil) yang kehadirannya masih tetap berarti, baik di wilayah pedesaan maupun perkotaan. Dalam pandangan Moeslim, kelas menengah muslim baru yang muncul pada era Orde Baru terletak pada penggunaan modal budaya dan modal pengetahuan. Pengetahuan di sini dipahami sebagai modal sosial, karena fungsinya tidak hanya mendukung tatanan masyarakat yangs sudah ada, melainkan mengangkat tatanan itu. ${ }^{29}$

Ada beberapa faktor yang menyebabkan mengapa apresiasi keagamaan di kelas menengah sangat tinggi. Pertama, munculnya modernisasi yang digulirkan Orde Baru pada dasarnya penumbanganan ideologi komunis, lawan agama. Sehingga agama memperoleh legitimasi yang kuat bukan saja dalam konsolidasi ideologi nasional, tapi juga referensi spiritual. Kedua, bersamaan dengan tumbangnya Orde Lama, format kekuatan politik aliran yang didasarkan pada warna-warna kultural-primordialisme ikut mencair, akibat modernisasi politik melalui kebijakan depolitisasi dan perampingan, hingga terjadi desimbolisasi aliran. Islam dalam hal ini dilepaskan dari statusnya sebagai ideologi politik, ${ }^{30}$ sehingga masyarakat tidak merasa adanya hambatan untuk mengekspresikan keislamannya secara bebas tanpa harus terkait dengan polarisasi kekuatan politik formal.

Dengan keadaan seperti itu, agama kembali menonjol sebagai ekspresi kultural ketimbang politik, dakwah dan islamisasi berlangsung secara intensif, seperti pengajian yang disponsori oleh istri pejabat, artis dan pengusaha, pembinaan kerohaniaan di kantor-kantor pemerintah maupun swasta. Ketiga, diterapkannya pendidikan agama dari sekolah dasar hingga perguruan tinggi. Ini membuat masalah sosialisasi agama menemukan pijakan politiknya yang kuat. Sementara identitas agama dalam kehidupan politik semakin melemah. ${ }^{31}$ Dari ketiga faktor inilah, islam kultural semakin berkembang dan bersimbiosis dengan budaya konsumerisme.

Pertumbuhan gaya hidup kelas menengah di Indonesia dapat diamati berdasarkan beberapa indikasi, seperti meningkatnya

${ }^{29}$ Moeslim Abdurrahman, Bersujud di Baitullah: Ibadah Haji, Mencari Kesalehan Hidup, (Jakarta: Kompas, 2009), hlm. 5.

30 Moeslim Abdurrahman, Kang Thowil dan Siti Marginal, (Bandung: Pustaka Firdaus, 1995), hlm. 122.

31 Ibid., hlm. 150. 
pengeluaran konsumen untuk biaya tempat tinggal di perumahan baru yang menjanjikan kenyamanan dan kemewahan. Bagi Moeslim, melalui indikasi tersebut, kelas menengah yang sedang berkembang di Indonesia harus dilihat sebagai suatu pembangunan budaya. ${ }^{32}$ Di sini kita melihat bagaimana ekspresi Islam yang ditampilkan oleh kalangan kelas menengah. Ekspresi itu berbentuk simbol/antribut, ritual atau pun kegiatan keagamaan yang mampu mencitrakan kesalehan bergengsi. Menurut Moeslim, pencarian identitas keislaman dan apa makna Islam bagi kelas menengah ini lebih ditekankan pada pembentukan kesalehan, kemodernan dan gaya hidup. ${ }^{33}$

c. Konsumerisme

Seperti kelas menengah, Moeslim juga tidak membuat konsep baku mengenai konsumerisme. Ia hanya menjelaskan fenomena konsumerisme yang berkembang di kelas menengah perkotaan. Sepertinya Moeslim bersikap taken for granted dan menganggap masyarakat sudah paham dengan konsep tersebut.

Konsumerisme merupakan sesuatu yang tak terpisahkan dari kapitalisme. Kapitalisme mengkonstruksi nalar publik menjadi nalar instrumental dan dari logika kebutuhan ke logika hasrat. Di samping itu terbangunnya ruang sosial baru, bukan ruang mempertarungkan wacana, tapi ruang menggelorakan selera. Seperti pusat-pusat perbelanjaan; hyper-mart, mal-mal, mini market yang menjadi estalse orang kaya baru (OKB) mengkonsumsi komoditas yang bermerek, prestise, dan bergengsi.

Moeslim melihat keberadaan mal-mal tersebut bukan sekedar tempat perbelanjaan biasa, melainkan tempat untuk melakukan identifikasi diri sebagai bagian dari budaya konsumerisme. ${ }^{34}$ Misalnya orang yang makan di KFC atau minum kopi di Starbuck secara strata sosial lebih tinggi dari orang yang makan atau minum di warung tegal (warteg) atau warung kopi biasa. Tidak hanya tempat, objek-objek konsumsi pun turut mempertegas identitas seorang konsumen. Mereka yang terperangkap dalam budaya ini tentu saja kelas menengah yang berkembang di masa Orde Baru.

Menurut Moeslim, jati diri seseorang dalam budaya konsumerisme tidak ada. Karakter dan gambaran subjek yang terungkap di ruang publik hanya hasil konstruksi sistem kapitalisme. ${ }^{35}$ Barangkali apa yang dipahami

${ }^{32}$ Moeslim Abdurrahman, Bersujud di Baitullah, hlm. 6.

33 Moeslim Abdurrahman, Islam yang Memihak, hlm. 52.

34 Moeslim Abdurrahman, Islam sebagai Kritik Sosial, hlm. 4.

35 Ibid., hlm. 6. 
oleh Moeslim sejalan dengan Jacques Derrida, Jacques Lacan Michel Foucault, Jean Baudrillard dan Richard Rorty yang mengatakan matinya subjek dalam masyarakat kapitalisme, di mana subjek tidak dapat menentukkan apa yang dikehendaki, melainkan mengikuti pola dan sistem yang diberlakukan. ${ }^{36}$

\section{Kritik Moeslim Abdurrahman Terhadap Kelas Menengah Muslim Indonesia}

Keberadaan kelas menengah di manapun diharapkan menjadi agen perubahan sosial. Mereka tidak hanya tulang punggung ekonomi masyarakat, melainkan juga motor penggerak masyarakat melalui peran politiknya, terutama dalam proses demokratisasi. Apabila kelas menengah kuat, maka mekanisme demokrasi dapat diharapkan berjalan lancar.

Di Indonesia, kelas menengah tumbuh-berkembang pada masa Orde Baru. Kelas menengah ini lahir dari latar belakang pendidikan yang relatif baik dan menikmati hasil pertumbuhan ekonomi yang stabil. Mereka merupakan kaum muslimin kota yang kesalehannya sudah tertanam sejak menerima pelajaran agama di sekolah, yang diharuskan oleh politik pendidikan orde baru. Atas pendidikan agama yang diperoleh dari sekolah dan pengajian itu, maka secara spesifik Moeslim menyebut mereka dengan kelas menengah muslim Indonesia.

Keberadaan kelas menengah muslim ini, secara politik menjadi bagian dari kekuatan yang mengambang dan mengapung. Hal lain yang mencolok dari kelas menengah baru di Indonesia adalah ketaatan mereka kepada Islam. Upaya untuk menunjukkan identitas keislaman di ruang publik semakin kuat sembari meyakini bahwa Islam dapat bergandengan tangan dengan modernitas. Mereka hadir dalam kondisi deparpolisasi Islam. Islam tidak lagi tampil dalam ideologi politik, melainkan Islam yang berwajah kultural. Oleh karenanya, sikap keislaman kelas menengah ini didapat dan diungkap dalam majelis atau pengajian.

Di samping itu, opini dan keluasan wawasan kelas menengah muslim terbentuk dari rutinitas membaca koran, majalah, berita televisi (TV) dan internet. Mereka meyakini bahwa wadah politik bukanlah tempat yang tepat untuk menyalurkan karir politik, karena jalur politik tidak memberikan kepastian. ${ }^{37}$ Di sini, keberadaan kelas menengah muslim

36 Yasraf Amir Piliang, Dunia yang Dilipat: Tamasya Melampaui Batas-Batas Kebudayaan, hlm. 302.

37 Moeslim Abdurrahman, Semarak Islam, Semarak Demokrasi?, (Bandung: Pustaka Firdaus, 1996), hlm. 3 dan 7.

70 JURNAL LISAN AL-HAL 
mulai mengidap sindrom apatisme terhadap politik.

Kalau kita mengharapkan kelas menengah muslim menjadi agen perubahan dan demokratisasi yang peduli terhadap pentingnya distribusi sosial dan ekonomi, rasanya dibutuhkan waktu yang agak panjang, terutama bagaimana melakukan intervensi dakwah agama yang lebih transformatif. Yaitu mengetengahkan pedagogis agama yang lebih dialektikal terhadap soal kemiskinan sebagai kemungkaran yang menjadi musuh keimanan. Inilah soal yang lebih ideologis daripada sekedar pertanyaan apakah kelas menengah Islam mendukung gagasan politik multikulturalisme, sebab mereka beragama dalam a-politis dalam arti tidak mempunyai kesadaran kritis-emansipatoris. ${ }^{38}$

Kelas menengah baru di Indonesia yang lebih saleh ini lahir dari proteksi dan koneksi kekuasaan orde baru yang tentu saja tidak mungkin diharapkan memiliki sikap otonom, apalagi mampu menjalankan sikap oposisi dengan negara dan pasar. Kita melihat kelas menengah Islam yang saleh ini tidak jelas kemana arah referensi kesadaran politiknya dan ternyata mereka tetap memilih sikap menunggu sampai lebih jelas, untuk memutuskan lebih baik lewat mana memperjuangkan hak-hak politik mereka, tapi yang jelas bahwa mereka bukanlah pendukung civil Islam yang resmi. Dunia sosial mereka seolah-olah lebih banyak dipengaruhi bagaimana menjadi partisipan pasar yang baik dan bukanlah menjadi warga negara yang kritis. ${ }^{39}$ Obsesi kelas menengah ini lebih mementingkan bagaimana memiliki pengalaman menikmati berbagai gaya hidup konsumeristik ketimbangan kesadaran politik citizenship. Mereka lebih peka terhadap etika konsumtif dan tidak terlalu peduli terhadap ideologi politik, karena secara individualistik mereka sangat menekankan "right to enjoy, no duty to suffer".40

Kelas menengah sadar bagaimana menjadi consumer citizen yang saleh dibanding mau mengambil resiko untuk bergabung dengan kekuatan perubahan. Di samping itu, mereka lebih tertarik mengambil agama sebagai selimut spiritual dan penguat jiwa, dibanding Islam sebagai kritik sosial dan mencegah kemungkaran. ${ }^{41}$ Padahal kondisi masyarakat di dalam sistem kapitalisme, kesenjangan-sosialnya semakin lebar. Orang yang kaya semakin kaya, karena memiliki kemampuan dan kesempatan untuk memutar uangnya, guna menghasilkan keuntungan yang lebih besar

\footnotetext{
38 Moeslim Abdurrahman, Islam yang Memihak, hlm. 52-53.

${ }^{39}$ Ibid., hlm. 55.

40 Moeslim Abdurrahman,, Suara Tuhan, Suara Pemerdekaan, hlm. 105.

41 Ibid., hlm. 53.
} 
lagi. Sementara, orang yang miskin semakin sulit hidupnya, karena harga barang makin tinggi, sementara daya beli justru semakin menurun.

Globalisasi yang menyebabkan konsumerisme ini tidak hanya berkembang di Barat, melainkan juga tumbuh di dunia ketiga, dalam hal ini masyarakat Timur. Biasanya Timur identik dengan tradisi agama. Asimilasi antara budaya konsumerisme dengan tradisi agama Timur melahirkan suatu budaya baru yaitu masyarakat konsumerisme yang shaleh, khususnya di Indonesia. Mengguritanya kapitalisme yang menghadirkan konsumerisme berbanding lurus dengan kebangkitan kelas menengah baru di masa Orde Baru ini seperti "kata berjawab, gayung bersambut".

Sebagai lapisan orang kaya baru, kelas menengah ini memiliki fasilitas mewah seperti mobil luxuries, kartu kredit, rumah yang memiliki penjaga dan lainnya. Tapi dalam waktu bersamaan, mereka merasa belum sempurna kalau tidak dapat bercerita pengalaman saleh yang juga bergengsi. Termasuk paket perjalanan haji dan paket buka puasa bersama yang ditawarkan oleh hotel-hotel berbintang yang menguras biaya cukup mahal. ${ }^{42}$ Mereka memenuhi kegiatan-kegiatan keagamaan massal seperti pengajian dan zikir akbar.

Tidak mengherankan, busana muslim, seperti jilbab dan baju koko dengan mode trendi dan gaya warna-warni mulai dominan di masyarakat. Selain itu juga semakin populernya qasidah, nasyid, program-program keagamaan di televisi termasuk sinetron bernuasa agama, penerbitan majalah dan buku-buku populer Islam. Semua bentuk objek-objek komoditas ini menjadi konsumsi kelas menengah.

Simbol dan atribut keagamaan yang menjadi tanda-tanda kesalehan selama ini telah berubah fungsinya secara radikal. Cara berpakaian, sebagai bagian dari paket gaya hidup yang gemerlapan dengan desain dan bahan baku khas dimiliki bukan karena semata-mata fungsi dan nilai keagamaannya yang asli. Misalnya, perkembangan busana muslimah hasil rancangan mutakhir yang menjual produknya dengan harga mahal yang tidak hanya sekedar kepentingan menutup aurat, melainkan mampu menampakkan keterpesonaan religiusitas yang bergengsi. Contoh lainnya, orang berani membeli sebuah kaligrafi dari ukiran Jepara senilai 10 juta bukan kualitas seninya, tetapi lebih pada pertimbangan gengsinya.

Ungkapan kesalehan bagi orang-orang berduit harus dibungkus dalam kemasan antara modernitas dan gaya hidup bergengsi. Contoh yang paling detil dikemukakan Moeslim adalah ibadah Haji plus (haji turistik)

42 Moeslim Abdurrahman, Islam sebagai Kritik Sosial, hlm. 2-3.

72 JURNAL LISAN AL-HAL 
yang merupakan riset disertasinya ketika studi S3 di Univesity of Illinois, Urbana-Campaign, US. Fenomena meningkatnya jamaah haji terjadi pada masa Orde Baru. Ibadah ini menjadi bagian penting dari legitimasi keagamaan, sosial, dan politik kelas menengah dan atas di Indonesia. Bersamaan dengan makin maraknya fenomena ini, kapitalisme dan konsekuansinya yakni turisme komersial dalam skala besar juga berkembang. Biro-biro perjalanan belakangan ini menawarkan berbagai paket perjalanan haji mewah atau haji plus. ${ }^{43}$

Haji plus berbeda dengan haji tradisional dalam berbagai hal penting. Pertama, kualitas akomodasi, hotel-hotel berbintang merupakan keharusan dalam haji plus. Kedua, transportasi mewah, ber-AC, tempat duduk yang menyenangkan, makanan dan minum selalu tersedia dan sopir yang profesional. Ketiga, peserta haji plus didampingi oleh pemimpin agama yang terkemuka. Keempat, makanan dan minuman selalu disediakan masakan Indonesia oleh koki profesional.

Sedangkan haji tradisional, dari sisi penginapan seadanya, transportasi yang digunakan adalah bus-bus yang dipenuhi jamaah sehingga penuh-sesak dan berhawa panas, dengan fasilitas yang minim. Dalam soal makanan dan minuman, para jamaah haji tradisional sangat minim, bahkan ada yang masak sendiri-sendiri.

Islam yang menjadi bagian dari budaya konsumerisme kini berfungsi sebagai penanda identitas yang penting. Bahkan secara bertahap muncul sebagai simbol elitisme. ${ }^{44}$ Suatu kesalehan yang cita-citanya dibelah dalam garis kelas sosial seperti antara orang kaya yang pergi haji dengan segala fasilitas dan orang kebanyakan yang berdesakan dalam bus yang panas selama di tanah suci. Biarpun mereka dalam berpakaian ihram yang menjadi simbol paling sentral dari ziarah suci ini semestinya mengajarkan ideologi sosial tentang egalitarianisme paling radikal dalam Islam. ${ }^{45}$

Di kondisi yang serat dengan ketimpangan sosial sekarang ini, kesalehan memang mewarnai kehidupan masyarakat. Walaupun dari segi penampilan menunjukkan terbelahnya garis sosial yang berbeda-beda. Menurut Moeslim, kebutuhan untuk membeli simbol dan atribut yang bernuansa religius tidak lain sekedar menunjukkan kesalehan di mata publik. $^{46}$

${ }^{43}$ Moeslim Abdurrahman, Bersujud di Baitullah, hlm. 32.

44 Noorhaidi Hasan, "Kelas Menengah Muslim dan Pemimpin Indonesia Masa Depan", Maarif, hlm. 116.

45 Moeslim Abdurrahman, Islam sebagai Kritik Sosial, hlm. 8.

46 Moeslim Abdurrahman, Suara Tuhan, Suara Pemerdekaan, hlm. 18. 
Dalam budaya konsumerisme, sebenarnya jati diri seseorang yang asli tidak ada. Karakter dan gambaran subjek merupakan sesuatu yang dikonstruksi oleh sistem kapitalisme. Subjek-subjek masyarakat adalah kumpulan konsumen yang menjadi pembeli terhadap cerita, ide, ilusi yang ditawarkan periklanan.

Pertanyaannya, apakah agama memiliki kepekaan untuk menjawab timbulnya the consumer society sebagai tantangan moralitas? Jika jawabannya ya, maka yang diperlukan adalah pentingnya peran agama sebagai moralitas dan menjadi ideologi sosial yang berhadapan dengan proses sosial yang kapitalis dan berwatak hedonistik. Agama seyogyanya peka untuk melakukan konsolidasi humanistis, tatkala manusia dikepingkeping dalam kesadaran sebagai hamba "merek dagang" ketimbang sebagai hamba Tuhan yang memiliki tanggungjawab atas terwujudnya masyarakat adil dan makmur. ${ }^{47}$

Kondisi akan semakin parah, manakala agama berusaha mengharmonisasikan diri dengan ideologi konsumerisme (berbentuk iklan), hanya semata-mata agar orang-orang kaya baru itu tetap menjaga kesalehan-kesalehan ritusnya, sambil memboroskan uangnya untuk konsumsi kapitalistis belaka. Tanpa Islam yang berwajah asketis sebagai alternatif, fungsi agama yang sesungguhnya harus menyuarakan solidaritas kemanusiaan akan menjadi redup.

Semestinya, Islamisasi yang terjadi pada kalangan kelas menengah sejak orde baru harus kita lihat dari ukuran moralitas ideologis (kesadaran kritis-emansipatoris). Yakni bagaimana mereka mencari identitas agama dan apa makna agama bagi pencarian hidup bersama yang lebih baik. Dalam pengamatan Moeslim, pencarian keislaman kelas menengah sekarang lebih dibentuk oleh pembentukan kesalehan, kemodernan dan gaya hidup. ${ }^{48}$

Di masyarakat konsumerisme, kesalehan sangat ditentukan oleh daya beli dan kemampuan material. Semakin kaya seseorang, maka orang tersebut akan semakin mampu menampilkan ketakwaannya yang lebih bergengsi di mata publik, dan begitu pula sebaliknya. Seperti itulah bentuk keberagamaan dan identitas keislaman kelas menengah yang menjadi bagian konsumerisme. Di sini Moeslim menegaskan bahwa agama mengalami keredupan dan kehilangan daya emansipatoris, liberatif dan tak berdaya menghadapi persoalan dehumanisasi, kemiskinan struktural

${ }^{47}$ Moeslim Abdurrahman , Islam sebagai Kritik Sosial, hlm. 6

48 Moeslim Abdurrahman, Islam yang Memihak, hlm. 51-52. 
dan berbagai krisis kemanusiaan yang semakin menonjol. ${ }^{49}$

Pencarian keislaman kelas menengah sekarang menurut Moeslim lebih dibentuk oleh pembentukan kesalehan, kemodernan dan gaya hidup. ${ }^{50}$ Oleh karena itu, jangan heran jika simbol dan ritual keagamaan memiliki fungsi baru yaitu sebagai penanda strata, status dan prestise di kalangan kelas menengah yang modern dan kapitalistik untuk tetap menunjukkan jati diri sebagai orang shaleh.

Kondisi seperti inilah yang menyebabkan Islam sebagai nilai mengalami erosi makna. Bagi Moeslim, Islam merupakan ruh kemanusiaan paling sejati yang menuntun perubahan, terutama dalam liberasi-emansipasi, baik bagi kesadaran orang perorang maupun secara kolektif untuk mewujudkan keadaban dan peradaban. Akan tetapi, dalam kondisi pergesaran kesadaran saat ini, Islam sering kali telah kehilangan panggilan sucinya sebagai motivasi perubahan, sebagai sumber gagasan gerakan sosial, dan bahkan sebagai kekuatan kesadaran kolektif untuk membangkitkan dan menegakkan cita-cita keadilan sosial yang telah redup dan rapuh. Islam sebagai kesadaran sosial yang bergerak di luar ritual mengalami pendangkalan makna. Hal ini disebabkan makna Islam yang berwatak emansipatoris tidak tumbuh menjadi bagian teks-sosial yang diperebutkan. ${ }^{51}$ Kesalehan hanya muncul dalam wajahnya yang eskapistik, sekedar menentramkan batin dan berwajah simbolik, sehingga sekat antara warna kesalehan kelas menengah dengan orang miskin yang tercecer dari mobilitas sosial semakin kentara.

Moeslim sangat mengkritisi kesalehan ritualistik yang lebih banyak dipertontonkan di hadapan publik dengan ungkapan yang mahal dan bergengsi dibandingkan sebagai kekuatan spiritual yang asketik tentang pentingnya menegakkan nilai-nilai kesetaraan yang lebih manusiawi. Bahkan yang amat memilukan, jika agama mengharmoniskan agama dengan ideologi iklan, hanya semata-mata agar orang-orang kaya baru itu tetap menjaga kesalehan-kesalehan ritusnya, sambil memboroskan uangnya untuk konsumsi-konsumsi kapitalistik.

Apa makna kesalehan seseorang sementara di sekitarnya ketimpangan dan keterpurukan sosial semakin meluas? Sebuah kesalehan tidak akan memberikan makna yang sejati, jika tidak mengalirkan makna perubahan sosial. ${ }^{52}$ Semestinya semakin kuat kesalehan seseorang, maka

${ }^{49}$ Moeslim Abdurrahman, Suara Tuhan, Suara Pemerdekaan, hlm. 21.

50 Moeslim Abdurrahman, Islam yang Memihak, hlm. 52.

51 Moeslim Abdurrahman, Suara Tuhan, Suara Pemerdekaan, hlm. 7-11.

52 Ibid., hlm. 12. 
semakin menguat pula kesadaran emansipasi dalam membongkar proses dehumanisasi. Justru yang terjadi sebaliknya, kesalehan kelas menengah Islam tidak berbanding lurus dengan realitas sosial yang timpang. Mereka semakin hanyut dengan pola dan gaya hidup konsumtif sembari meningkatkan citra yang religius dan prestisius di hadapan publik.

\section{Simpulan}

Budaya konsumerisme merupakan sebuah budaya konsumsi yang ditopang oleh proses penciptaan diferensiasi secara terus-menerus lewat penggunaan objek-objek komoditas, sebuah budaya belanja yang proses perubahan dan perkembangbiakannya didorong oleh logika hasrat dan keinginan ketimbang logika kebutuhan. Melalui mesin produksi kapitalisme, orang dikondisikan untuk menginginkan sesuatu yang tidak dibutuhkannya. Embrio konsumerisme muncul pasca revolusi industri di Eropa di mana kapitalisme memiliki peran yang dominan dalam sistem sosial.Sifat konsumerisme juga terjadi pada kalangan islam. Dimana konsep islam menurut Moeslim adalah Islam yang mampu menggugah kesadaran emansipatoris yang membawa pada perubahan sosial. Moeslim sendiri memproklamirkan bahwa konsep keislamannya adalah Islam transformatif. Menurut Moeslim Konsumerisme merupakan sesuatu yang tak terpisahkan dari kapitalisme. Kapitalisme mengkonstruksi nalar publik menjadi nalar instrumental dan dari logika kebutuhan ke logika hasrat. Di samping itu terbangunnya ruang sosial baru, bukan ruang mempertarungkan wacana, tapi ruang menggelorakan selera. Seperti pusat-pusat perbelanjaan.

Menurut Moeslim spirit syari'at dalam agama islam telah terkontaminasi dengan adanya budaya konsumerisme yang Simbol dan atribut keagamaan yang menjadi tanda-tanda kesalehan selama ini telah berubah fungsinya secara radikal. Cara berpakaian, sebagai bagian dari paket gaya hidup yang gemerlapan dengan desain dan bahan baku khas dimiliki bukan karena semata-mata fungsi dan nilai keagamaannya yang asli. Diantaranya juga ungkapan kesalehan bagi orang-orang berduit harus dibungkus dalam kemasan antara modernitas dan gaya hidup bergengsi, seperti kasus ibadah Haji plus (haji turistik). Kondisi ini sarat dengan ketimpangan sosial. Kesalehan memang mewarnai kehidupan masyarakat. Walaupun dari segi penampilan menunjukkan terbelahnya garis sosial yang berbeda-beda. Menurut Moeslim, kebutuhan untuk membeli simbol dan atribut yang bernuansa religius tidak lain sekedar menunjukkan kesalehan di mata publik

76 JURNAL LISAN AL-HAL 


\section{DAFTAR PUSTAKA}

Abdurrahman, Moeslim, Bersujud di Baitullah: Ibadah Haji Mencari Kesalehan Hidup, Jakarta, Kompas, 2009.

---------------, Kang Thowil dan Siti Marginal, Bandung, Pustaka Firdaus, 1996.

Firdaus, 1996.

------------, Islam Sebagai Kritik Sosial, Jakarta, Erlangga, 2003.

---------, Islam yang Memihak, Jogjakarta, LKiS, 2005

--------------, Suara Tuhan, Suara Pemerdekaan, Jogjakarta, Kanisius, 2009.

Bakker, Anton dan Achmad Charris Zubair, Metodologi Penelitian Filsafat. Jogjakarta: Kanisius, 1992.

Baudrillard, Jean,The Consumers Society: Myths and Structures, London, Sage, 1998.

Fadhilah, Relevansi Logika Sosial Konsumsi dengan Budaya Konsumerisme dalam Perspektif Epistemologi Jean Baudrillar, Jurnal Kybernan, II (1): 39-57, 2011.

Hasan, Noorhaidi. "Kelas Menengah Muslim dan Pemimpin Indonesia Masa Depan", Jurnal Maarif, VIII (2): 111-128, 2013.

Latif, Yudi, Intelegensia Muslim dan Kuasa: Genealogi Intelegensia Muslim abad ke-20. Bandung, Mizan, 2005.

Mackie, J.A.C., Uang dan Kelas Menengah, Dalam Richard Tanter dan Kenneth Young, Politik kelas menengah Indonesia (hal. 122-126), Jakarta, LP3ES, 1996.

Munawar-Rahman, Budhy, Islam Pluralis, Jakarta, Paramadina, 2001.

Pambudy, Ninuk M, Gaya Hidup Suka mengonsumsi dan Meniru: Beranikah Berinovasi?, Prisma, XXXI (1): 14-27, 2012.

Piliang , Yasraf Amir, Bayang-Bayang Tuhan: Agama dan Imajinasi, Bandung, Mizan, 2011.

----------------- Dunia yang Dilipat: Tamasya Melampaui Batas-Batas Kebudayaan, Bandung, Matahari, 2010.

Prabowo, M. Nur, Meretas Kebahagiaan Utama di Tengah Pusaran Budaya Konsumerisme Global: Perspektif Etika Keutamaan Ibn Miskawaih, Mukaddimah, XIX (1): 65-88, 2013.

Rahardjo, M. Dawam, Masyarakat Madani: Agama, Kelas Menengah dan Perubahan Sosial, Jakarta, LP3ES dan LSAF, 1999.

Ritzer, George, Introduction, on Jean Baudrillard, The Consumers Society: 
Myths and Structures (hal. 1-25), London, Sage, 1998.

Soedjatmiko, Saya Berbelanja, Maka Saya Ada, Jogjakarta, Jalasutra, 2008.

Vatikiotis, Michael R.J, Political Change in Southeast Asia, Trimming the Banyan Tree, London and New York, Routledge, 2005.

Wirosardjono, Soetjipto, Kelas Menengah Mencari Bentuk dan Pengakuan, Prisma, XIII (2): 71-72,1986.

Yuswohadi, siapa Kelas Menengah, 26 November 2012.

http://www.yuswohady.com/2012/11/26/siapa-kelas-menengah/ diakses 20 Maret 2016.

Kompas, Kelas Menengah Tidak Diantisipasi, 19 Desember 2011. http://bisniskeuangan.kompas.com/read/2011/12/19/07433945 LKelas.Menengah.Tidak.Diantisipasi, diakses 20 Maret 2016. 